\title{
Morphological Studies on the Gills of Puffer Fish (Lagocephalus sceleratus, Gmelin, 1789)
}

\author{
Estudios Morfológicos en Branquias del Pez Globo (Lagocephalus sceleratus, Gmelin, 1789)
}

Mohamed M. A. Abumandour* \& Mahmoud S. Gewaily**

ABUMANDOUR, M. M. A. \& GEWAILY, M. S. Morphological studies on the gills of puffer fish (Lagocephalus sceleratus, Gmelin, 1789). Int. J. Morphol., 34(3):817-829, 2016.

SUMMARY: In the present study, we focused on the morphology of L. sceleratus gills using gross anatomy, scanning electron microscopy as well as light microscopy. Results of this study revealed that the gill openings appeared as simple slits anterior to the pectoral fin without distinct opercular cover. The gill system consisted of three pairs of gill arches carrying two rows of gill rakers on its concave border and gill filaments on its convex border. SEM showed that all surfaces of the gill arch were characterized by the presence of the longitudinal ridges with many taste buds in addition to many spines around the rakers. Histologically, the gill arch was composed of curved bar of hyaline cartilage with slightly elevated area corresponding to the sites of gill rakers. Each filament was formed of a thin central cartilaginous core surrounded by peripheral cartilaginous ma

trix and covered by primary epithelial layer with abundant mucous cells. The chloride cells appeared mainly near to the base of secondary lamellae. Each gill filament gave rise to a very large number of secondary lamellae on both sides. The epithelial lining of the secondary lamellae comprised epithelial pavement cells, few mucous cells and pillar cells. The latter interposed the enriched blood capillaries. These findings suggest that $L$. sceleratus gills have characteristic morphological features that are related to adaptive functions for feeding habits, osmoregulation and respiratory mechanism with in their living environment.

KEY WORDS: Lagocephalus sceleratus; Gills; Anatomy; SEM; Histology.

\section{INTRODUCTION}

Lagocephalus sceleratus is considered a member of the fish family Tetrodontidae, which includes 187 different species worldwide (West, 2009; Homaira et al., 2010) and have many other generic names such as Puffer fish, blow fish, balloon fish, toad fish, and globe fish. It has a widespread distribution throughout the tropical Indian and Pacific Oceans; from Japan, Australia and Hong Kong in the east to Mozambique and southern African shores, as well as the Red Sea (Dor, 1984; Smith \& Heemstra, 1986; Watson et al., 2003).

L. sceleratus is one of the Lessepsian species of puffer fishes that has invaded the Eastern basin of the Mediterranean Sea from the red sea through the Suez Canal. It was first recorded in Gokova Bay, Turkey in 2003, while the previous 1977 record by Mneimné was a misidentification of the similar puffer fish Lagocephalus suezensis. L. sceleratus has already established a population which is colonizing new territories of the Eastern Mediterranean at a relatively rapid rate where it had reached the Aegean Sea in 2006, three years after it firstly appeared in Turkey in 2003 (Bilecenoglu et al., 2006; Kasapidis et al., 2007; Carpentieri et al., 2009; Pancucci-Papadopoulou et al., 2011).

Recently, it is regarded to be among the worst invasive species in the Mediterranean Sea with a significant impact on the surrounding ecosystem and on the fisheries sector (Zenetos et al., 2005; Peristeraki et al., 2006; Streftaris \& Zenetos, 2006). More importantly, L. sceleratus is considered to be a serious hazard to consumers since it contains a strong marine toxin called tetrodotoxin (TTX), which can be lethal to humans. Another important negative impact of L. sceleratus is related to complaints from local fishers that have become frequent in Egypt, Lebanon, Cyprus, Turkey and Greece where the destruction of nets due to attacks by $L$. sceleratus that can easily cut lines and nets using its strong teeth (Kalogirou et al., 2010). Also, it attacks fishes caught in nets and lines of fishers leading to reduction of local stocks of squids and octopus through predation (Nader et al., 2012).

\footnotetext{
* Department of Anatomy and Embryology, Faculty of Veterinary Medicine, Alexandria University, Behera, Egypt.

${ }^{*}$ Department of Anatomy and Embryology, Faculty of Veterinary Medicine, Kafrelsheikh University, Kafr Elsheikh, 33516, Egypt.
} 
Although L. sceleratus has significant economic, and ecological impacts on Eastern Mediterranean countries, most of the studies found around the world have targeted other species of puffer fishes, and therefore publications concerning $L$. sceleratus in particular are relatively scarce (Nader et al.). Moreover, most of previous data about $L$. sceleratus was related to general adaptive mechanism and their poisonous effect without approaching their morphology that may reflect important functional relationship, which affects their biology.

The study of the morphology of the different types of fish is a more interesting research area for many researchers in which there are attracted points in the gill as noted in many articles (Hughes \& Morgan, 1973; Laurent \& Hebibi, 1989; Goss et al., 1992; Balm, 1996; Zayed \& Mohamed, 2004; Saliu \& Olonire, 2008; Monteiro et al., 2011).

The gills are related to many important functions of all fishes; the first and important function is that the gills are considered the main respiratory sites of gas exchange in all fishes (Moyle \& Cech, 1996), while the secondary function is related to feeding habits where the organization of gill filaments and rakers were reflected to the feeding habits of the fish (Fernandes et al., 2003; Kumari et al., 2009), in which the organization and size of the gill rakers played a role in controlling the size of food particles eaten. Fish with many long rakers is filter feeders, whereas species with few short rakers are omnivores and carnivores (Moodie, 1985; Mummert \& Drenner, 1986). So, the present investigation was focus on the morphology of the gills of the puffer fish (L. sceleratus) including gross anatomy, scanning and histological study.

\section{MATERIAL AND METHOD}

Sample. Twenty mature fishes of $L$. sceleratus, their weights ranged $1300-1550 \mathrm{~g}$; the fishes were collected after catching from Mediterranean Sea, Edko, Behera governorate, Egypt and transported in plastic aquariums to our lab within $2 \mathrm{~h}$ to carry out the gross morphology, scanning electron and light microscopes study on their gills.

Gross morphological study. Ten fishes were used to display the morphological features. The skin was dissected and reflected to demonstrate the middle bony layer of gill covering. Subsequently, we removed this bony support to demonstrate the inner layer of gill covering. The latter was removed to illuminate the gill cavity with its contents. The boundaries of gill cavity were investigated. The diameters of gill opening as well as the length of gill arches were measured; the numbers of gill arches and gill rakers were detected. All the previous parts were carefully dissected and photographed by digital camera (Cannon IXY 325, Japan).

Scanning electron microscopic study. Four fishes were used. Small specimens from gills were taken immediately after catching. The samples were fixed in a glutaraldehyde $3 \%$ solution at $4{ }^{\circ} \mathrm{C}$ for $24 \mathrm{~h}$ then dehydrated through a graded series of acetone. After that, the specimens were postfixed in osmium tetroxide $1 \%$ in a phosphate buffer for $2 \mathrm{~h}$. The samples were subsequently dehydrated in ascending grades of ethanol followed by critical point drying in carbon dioxide. Then after, the samples were coated with gold and examined with JEOL JSM 5300 scanning electron microscope operating at $15 \mathrm{Kv}$, Faculty of Science Alexandria University.

Light microscopy. Small specimens $\left(0.5 \mathrm{~cm}^{3}\right)$ of the gill arches and the accompanying filaments and rakers were taken from six fishes in the fresh state. The samples were fixed in $10 \%$ formalin. After $24 \mathrm{~h}$, the samples were extensively transferred to $70 \%$ alcohol. The tissue samples were then dehydrated in ascending graded series of ethanol, cleared in xylene and impregnated and embedded in paraffin wax. Sections of 5-7 $\mu \mathrm{m}$ were cut using Leica rotatory microtome (RM 2035) and mounted on glass slides. Paraffin sections were used for conventional staining (H\&E). The histological techniques and stains were adopted according to Suvarna et al. (2013).

\section{RESULTS}

The gill system of the puffer fish (L. sceleratus) is confined within two interconnected gill chambers. The gill chambers are bounded ventrally by the mandible and three horizontal bony rods, dorsally by the roof of the buccal cavity, caudally by the base of pectoral fin and laterally by three layered gill covering, while medially they appear continuous with each other. The gill system consisted of three pairs of gill arches, which were termed from the lateral to medial as first, second and third. Each gill arch is general somewhat cresentric-shape carrying gill rakers on its concave border and gill filaments on its convex border (Figs. 1, 2, 3 and 4A).

External gill opening and gill covering. Entrance for the gills begins with slit-like opening without distinct opercular cover. It is presented cranial to the base of the pectoral fin and its vertical diameter reaches to $3.3 \mathrm{~cm}$. This gill opening is bound by the cutaneous flap and underlied by valve-like dark colored membrane which guards the opening (Fig. 1A, $\mathrm{B} / \mathrm{Og}$ and $\mathrm{V}$ ). 

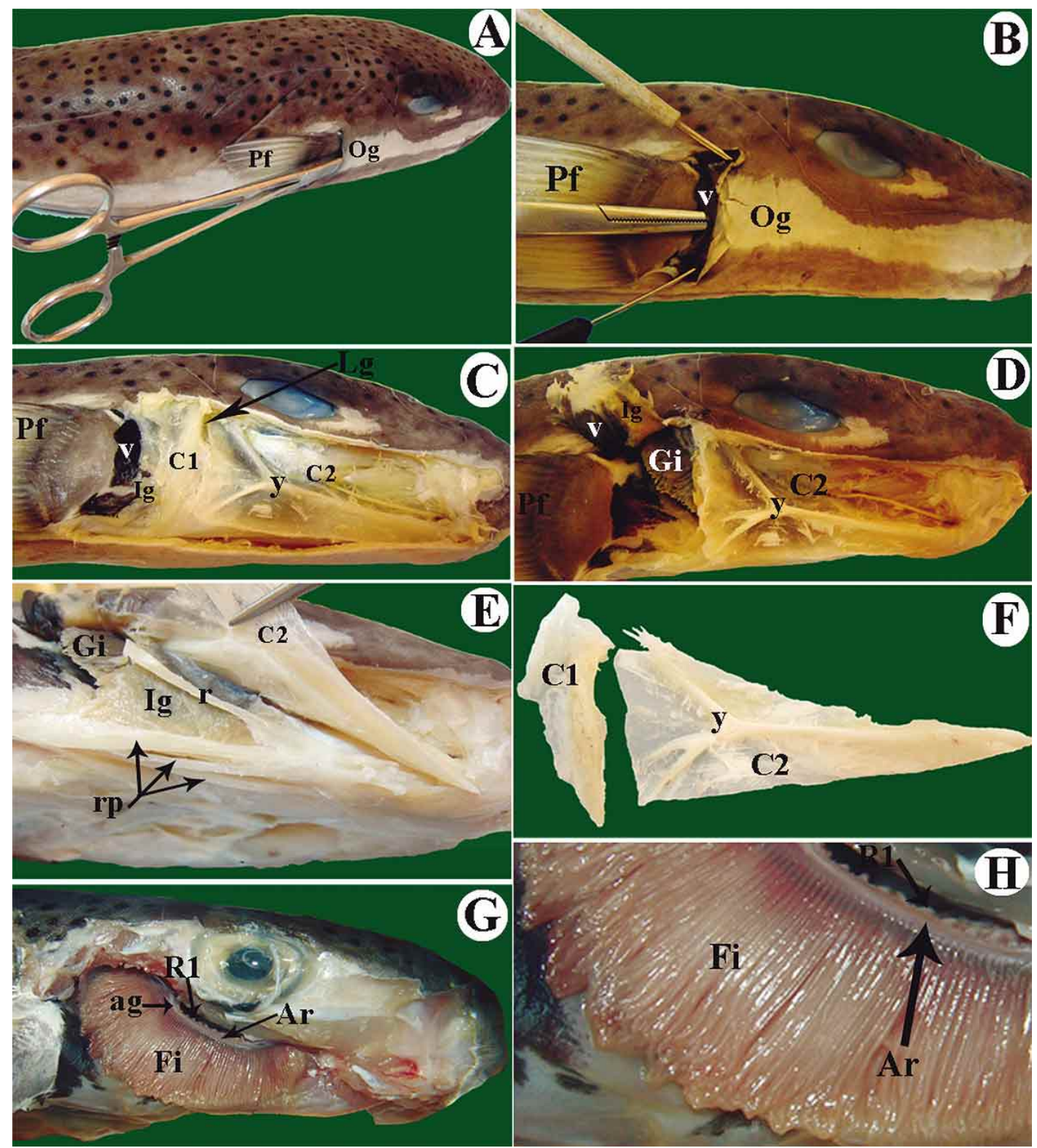

Fig. 1. Photographs of the head region of the puffer fish (L. sceleratus). View (A and B) showing the external gill opening (occupied by artery forceps) rostral to the pectoral fin (Pf) and the outer cutaneous layer $(\mathrm{Og})$ of gill covering. View (B) is showing the 1st layer of gill covering $(\mathrm{Og})$ and the underlying valve-like dark colored membrane (V) which guards the opening. View (C and D) are showing the 2nd layer of gill covering which is formed of two bony plates; vertical slightly movable plate caudally $(\mathrm{C} 1)$ and a large triangular immovable one rostrally $(\mathrm{C} 2)$ which characterized by a horizontal Y-shaped bony prominence (Y) on its lateral surface. $\mathrm{C} 1$ and $\mathrm{C} 2$ were connected by fibrous ligament $(\mathrm{Lg})$. More caudally, the inner layer $(\mathrm{Ig})$ of gill covering slightly rostral to guarding membrane (V) and pectoral fin (Pf). After removal of $\mathrm{C} 1$ and reflection of the inner layer (Ig) of gill covering, the gills (Gi) began to appear. View (E) clarifying the inner layer (Ig) which directly covers the gills (Gi) in addition to 4elongated bony rods; one of them (r) was located dorsally and converging rostrventrally to joins other ventral three rod-shaped bone plates (rp). View (F) referring to the isolated C1and C2. View (G and $\mathrm{H})$ referring to the head region with exposed gill chambers after removal of whole gill covering to note the gill filament (Fi), gill arch (Ar), lateral row of gill rakers (R1) and the angle (ag) between the epibranchial and ceratobranchial part of gill arch. 


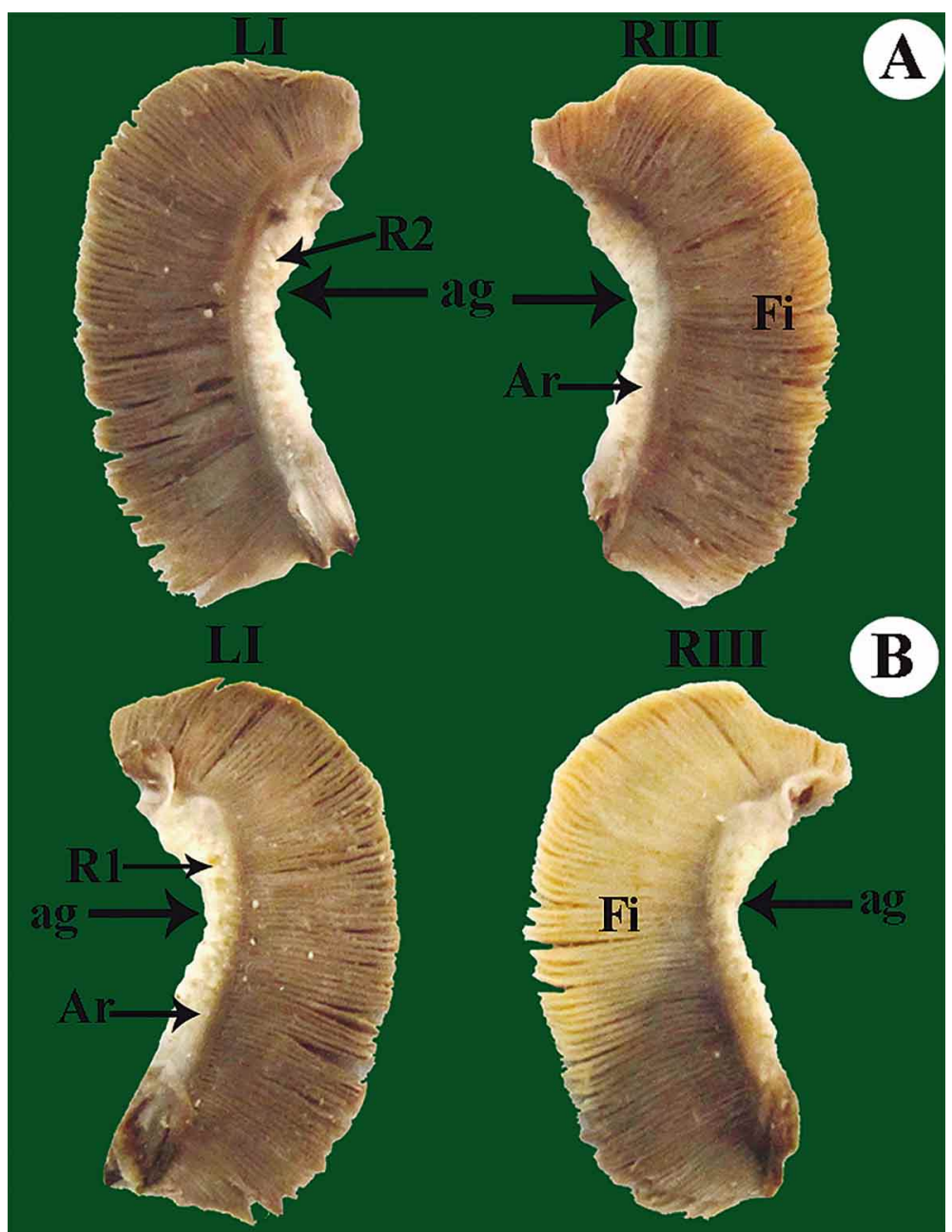

Fig. 2. Photograph of two separated gills of L. sceleratus from each side (left first gill arch (LI), right third gill arch (RIII)). View (A) is showing; the medial view of the two separated gill arches and View (B) clarifying the lateral view of the two separated gill arches. View (A and B) demonstrated that; the gill arch (Ar) is a cresentic-shape and oblique rostroventrally, carrying medial row R1and lateral row R2 of gill rakers and on its concave border and gill filaments (Fi) on its convex border. Fi appeared longer in the middle portion of the arch and being shorter toward the extremities. Lateral row of gill rakers (R1) is small while the medial row of the gill rakers (R2) is slightly larger. (ag) refer to the angle between the epibranchial and ceratobranchial part of gill arch.

Rostral to the gill opening, the lateral boundary of gills comprises three underlying layers. The outer cutaneous layer is interposed horizontally by white color strap which starts from the oral opening and extends along the whole length of fish (Fig. 1A, B/Og).

After reflection of this cutaneous layer, there are two bony plates; a vertical slightly movable plate caudally and a large triangular immovable bony plate which presents rostrally and occupies most of lateral boundary of gills. The base of latter is found nearly at the level of caudal margin of the eye. Moreover, this triangular bony plate has on its lateral surface a horizontal Y-shaped bony prominence (Fig. 1C, D, E and F). The two plates are connected by a connective tissue ligament (Fig. 1C). After removal of this triangular bony plate, there is an elongated rod-shaped bony plate attached to underlying muscular covering (third layer) which directly covered the gills and continued caudally until the gill opening. This rod-shaped bony plate is converging rostrally towards the mentum of fish, where it is joining other ventral three rod-shaped bony plates. The latter represented the ventral margin (boundary) of the gill chamber (Fig. 1E).

Gill arch. The gill arch has a cresentic-shape and oblique rostroventrally, carrying gill rakers on its concave border and gill filaments on its convex border (Figs. 1F and G, 2, 3A and B, and $4 \mathrm{~A}, \mathrm{~B}$ and $\mathrm{C}$ ). Each gill arch has two extremities; rostral and caudal. The rostral extremities of gill arches are united forming a wide interbranchial septum between the contra-lateral gills. The interbranchial septum appeared quadrilateral flattened dorsoventrally and carried line of small spiny rakers at the level ventromedial to the third gill arch (Fig. $3 \mathrm{~A}$ and $\mathrm{B})$.

The caudal extremities of the three arches appear curved dorsally. They are connected with each other and are attached to the dorsolateral wall of pharynx (Fig. 4B). The lengths of the three arches are measured $4.7 \mathrm{~cm}$, $4.5 \mathrm{~cm}$, and $4.1 \mathrm{~cm}$ respectively from lateral to medial. Each gill arch is divided into a long ceratobranchial part and short epibranchial part. Both parts are demarcated by slightly prominent angle. The length ratio of two parts is varied from one arch to another (decreased from lateral to medial) (Figs. 1G and 2/ag). The three arches are connected with each other rostrally and caudally.

By scanning electron microscope, the surface of gill arch is characterized by the presence of gill rakers with many spines around them (Fig. 3C, D, E and H). The gill arch has elevated parts noting the corresponding origin of gill filaments (Figs. 3F and 4D, E/Ep). At high magnification, all surfaces of the gill arch appeared to be characterized by the presence of the longitudinal parallel ridges with many taste buds (Fig. 3G-I). 


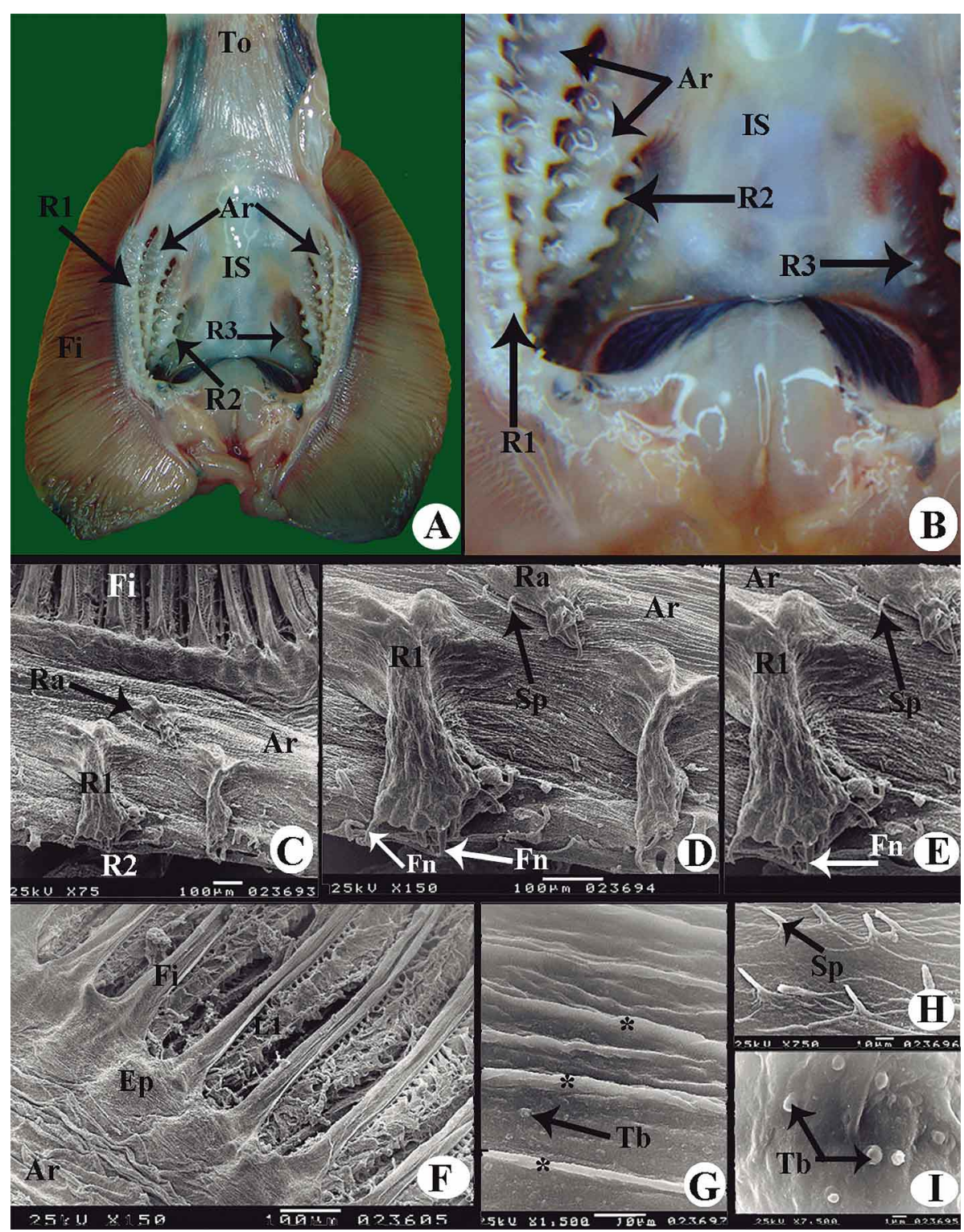

Fig. 3. Gross anatomical photographs (A, B) and scanning electron micrographs (C-I) of the $L$. sceleratus gills. View (A and B) showing; separate gill system: to determine the gill arch (Ar), gill filaments (Fi), lateral short gill rakers (R1), medial slightly longer gill rakers (R2), interbranchial septum (IS), line of rough spiny small rakers (R3) at the level ventromedial to the 3rd gill arch, and tongue (To). View (C) showing the gill arch (Ar), short lateral gill rakers (R1), long medial gill rackers (R2), accessory gill rakers (Ra) and the beginning of the gill filaments (Fi) (X 75). View (D and E) showing the gill arch (Ar), short lateral gill rakers (R1), accessory gill rakers $(\mathrm{Ra})$ and the spines on the gill arch while Fn refers to the pointed finger-like spines of different directions on the gill rakers (X 100). View (F) showing the wrinkled surface of the gill arch (Ar), the beginning of the gill filaments $(\mathrm{Fi})$ with its secondary lamellae originated from it (L1) and the elevated parts on gill arch determine the origin of the corresponding gill filaments (Ep) (X 150). View (G) is showing the surface of the gill arch at higher magnification(X 1500) with the presence of the longitudinal parallel ridges $(*)$ and taste buds $(\mathrm{Tb})$ which appeared more clearly in I (X 7500). View (H) showing presence of many spines of different directions on the surface of the gill arch (X 750).

By light microscope, the gill arch is composed of curved bar of hyaline cartilage surrounded by thin layer of peripheral cartilaginous matrix on both sides and covered by mucous epithelium (Fig.5). There are large branchial arteries coursed longitudinally beside the arches and give rise to an afferent arteriole to each gill filament (Fig. 5B-D). Each of these arteries gives off several capillaries that enter the lamellar epithelium along the filaments and secondary lamellae.

Gill rakers. The gill rakers are located on the concave internal side of the gill arches. Grossly, each gill arch has two rows of rakers; small lateral and slightly larger medial rakers (Figs. $1 \mathrm{G}$ and $\mathrm{H}, 2 \mathrm{~A}$ and $\mathrm{B}, 3 \mathrm{~A}$ and $\mathrm{B}$ and $4 \mathrm{~B}$, $\mathrm{C} / \mathrm{R}, \mathrm{R} 1$ and $\mathrm{R} 2$ ). The rakers of adjacent gill arches are interdigitated with each other (Fig.3B). The average numbers of the gill rakers appeared slightly variable in the different gills where, the number of rakers on the lateral rows of the 1st, 2nd, and 3rd gill arches were 17 and 12 and 11 rakers respectively, while on the medial rows were 17,15 and 12 respectively. The length of gill rakers is nearly the same in all gill arches (about $2 \mathrm{~mm}$ for medial row and $1 \mathrm{~mm}$ for lateral ones).

By SEM, the gill rakers appeared as short projected bodies with lobulated wide apex (Fig. 3C, D, E/R1 and R2). Many pointed finger-like spines of different directions protrude from the apices of rakers (Fig. 3D and $\mathrm{E} /$ white arrow). In addition to the lateral row of rakers, there are accessory rows of smaller gill rakers (Fig.3C and D/Ra). The rakers of accessory row are interposed the rakers of lateral row. The accessory rakers appeared as a short triangular with wide-based and pointed apex and lateral surface divided into two halves by centrally 


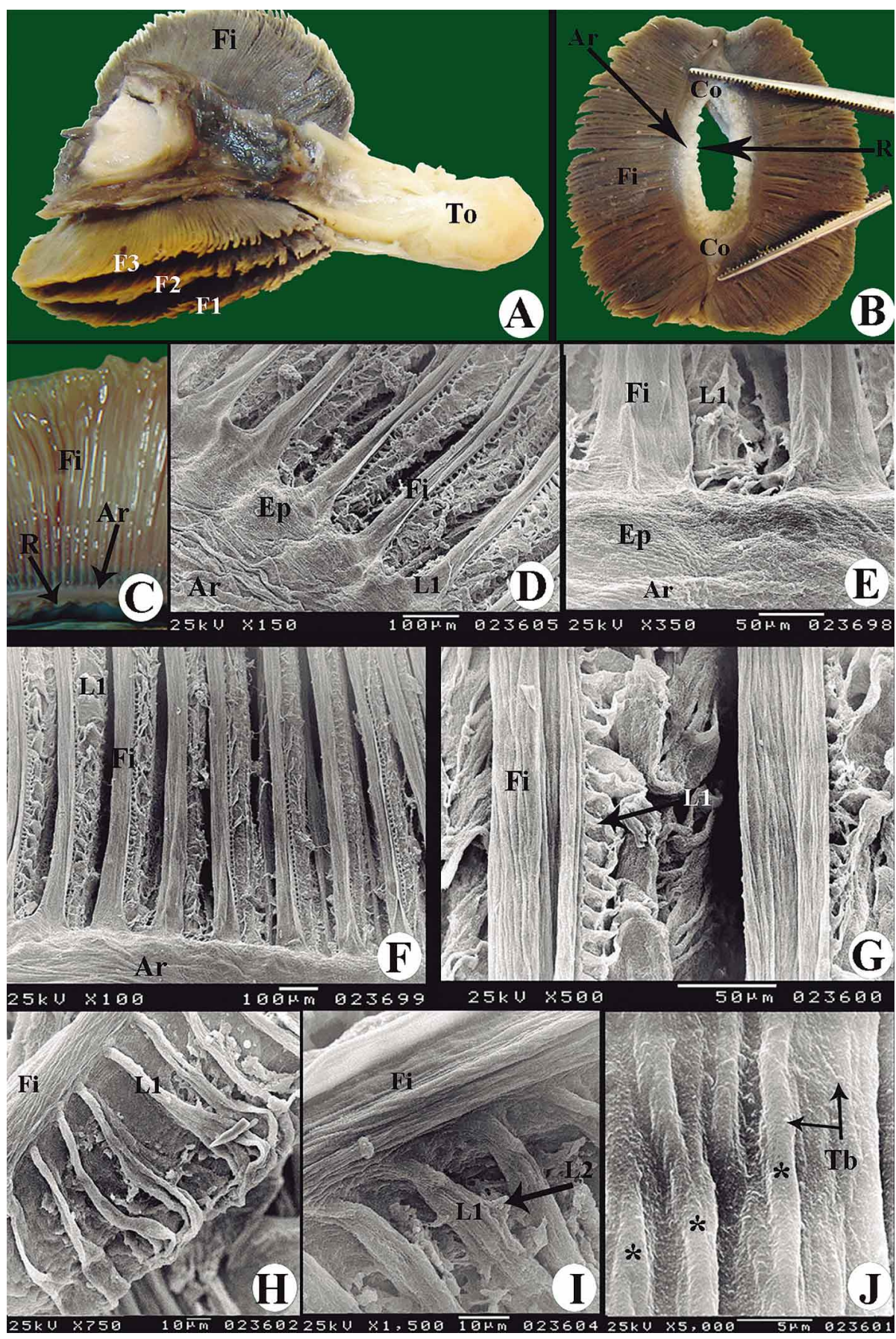

Fig. 4. Gross anatomical photographs (A-C) and scanning electron micrographs (D-J) of the $L$. sceleratus gills. View (A, B and C) showing; The separate gill system to determine the gill arch (Ar), gill filaments (Fi), gill filaments of first gill arch (F1), gill filaments of second gill arch (F2), gill filaments of third gill arch (F3), gill rakers (R), tongue (To), while (Co) pointed to the connection between the two gill arches. View (D) showing the gill arch (Ar), the beginning of the gill filaments $(\mathrm{Fi})$ with its secondary lamellae (L1) originated from it and the elevated parts on gill arch determine the origin of the corresponding gill filaments (Ep). The higher magnification in View (I) showing the tertiary lamellae (L2) which originated from the secondary lamellae (L1). View (J) clarifying the surface of the gill arch to note the presence of parallel longitudinal rows of epithelial cells (*) and many taste buds (Tb). The magnification was (X 150) for D, (X 350) for $\mathrm{E},(\mathrm{X}$ 100) for F, (X 500) for $\mathrm{G}$ and (X 750) for H; (X 1500) for I and (X 5000) for J. located projected ridge. There are many spines present around the gill rakers (Fig. 3D, E and $\mathrm{H} / \mathrm{Sp})$.

Histologically, the gill rakers appear as convex elevated areas bulged cranially on the concave side of gill arch and found contra laterally to the gill filaments. These elevations are mainly composed of cartilaginous core covered by collagenous matrix (Fig. 5A)

Gill filaments. The gill filaments are branched from the convex external surface of the gill arch in a perpendicular manner, pointing toward the gill cavity. Each gill filament is called a holobranch which in turn is formed of two welldeveloped compactly adherent hemibranches (lateral and medial hemibranches) (Fig. $1 \mathrm{G}$ and $\mathrm{H}, 2 \mathrm{~A}$ and $\mathrm{B}, 3 \mathrm{~A}, 4 \mathrm{~A}, \mathrm{~B}$ and C). The length of gill filaments has a little variation along the whole length of gill arches, where, the gill filaments appeared longer in the middle portion of the arch (about 1.8 $\mathrm{cm}$ ) while being shorter toward the extremities (about $0.6 \mathrm{~cm}$ in the proximal extremity caudally and about $0.4 \mathrm{~cm}$ in the distal extremity of the gill arch rostrally).

By SEM, the gill filaments are considered to be the primary lamellae (Fig. 4D$\mathrm{I} / \mathrm{Fi}$ ) from which leaf like secondary lamellae branched from both sides and originated at the right angles to the longitudinal axis of the filaments. The secondary lamellae are lying parallel to each other (Fig. 4D-I/L1). Moreover, there are some tertiary lamellae arising from the 


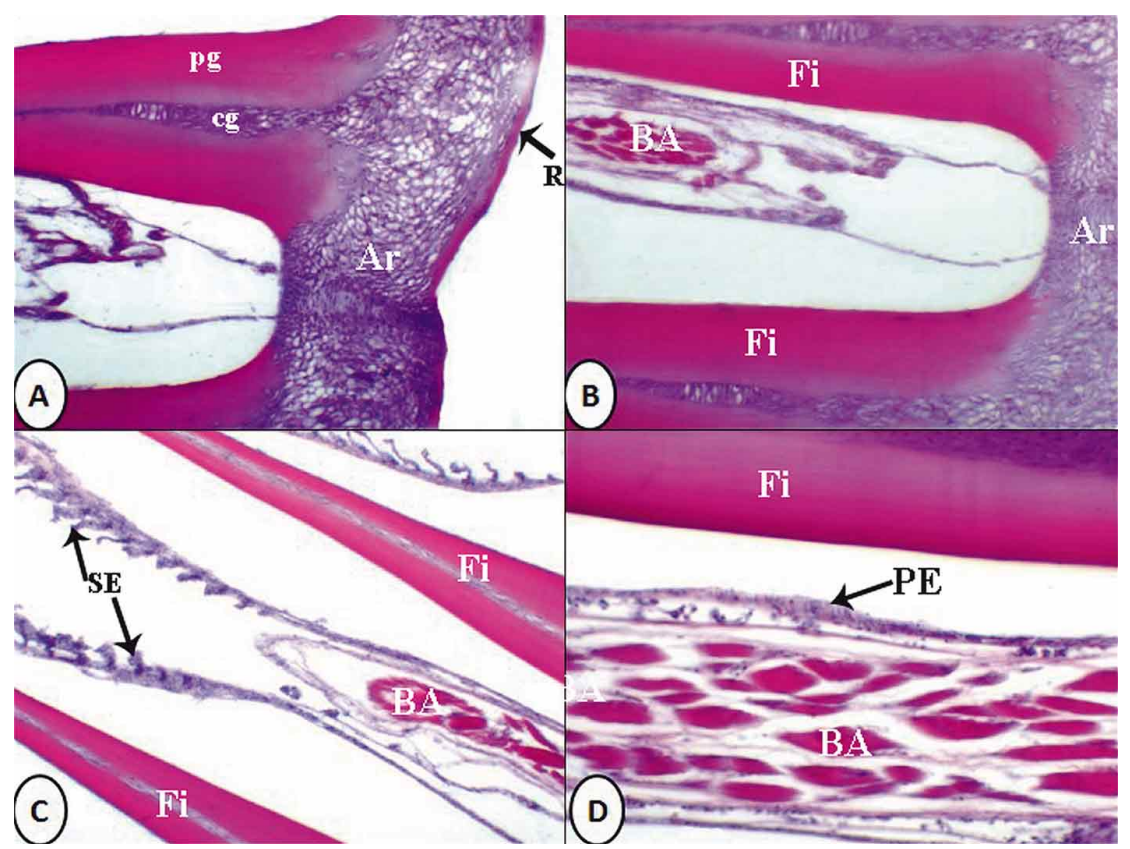

Fig. 5. Photomicrographs of the L. sceleratus gills showing, gill arch (Ar), gill raker (R), gill filaments $(\mathrm{Fi})$ which formed of central cartilaginous core $(\mathrm{cg})$ and peripheral cartilaginous matrix (pg). Note the branchial artery (BA) in between gill filaments near the site of arising from the gill arch. PE refers to primary lamellar epithelium while SE refers to secondary lamellar epithelium. Stain H\&E. X100 in A, B and C while X200 in D.

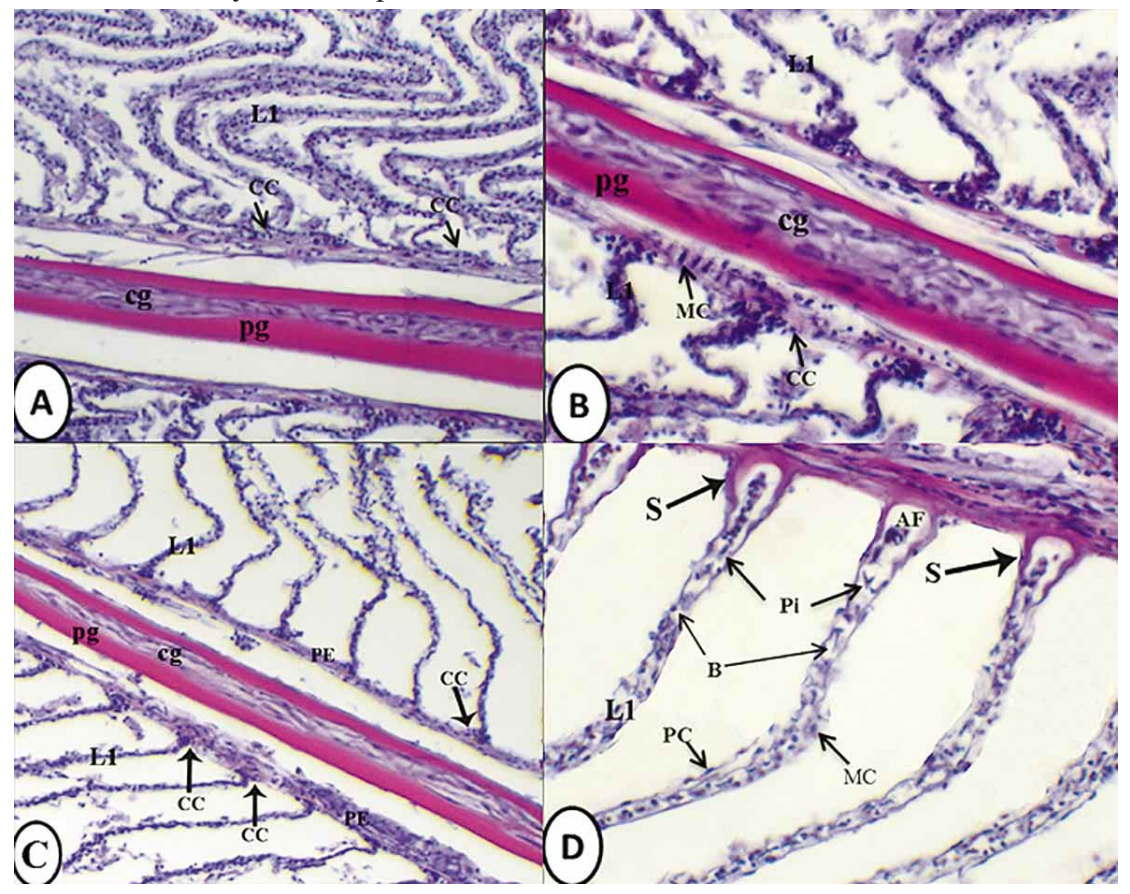

Fig. 6. Photomicrographs of the L. sceleratus gills showing Gill filaments which formed of central cartilaginous core (cg) and peripheral cartilaginous matrix (pg) and the epithelial lining of both filaments and secondary lamellae. The epithelial lining of gill filaments (PE) comprises abundant mucous cell (MC) as well as chloride cells (CC) while the secondary lamellar epithelium comprise pavement cell (PC), pillar cells (PI), blood capillaries (B) as well as few mucous cells (MC). Note the afferent arterioles (AF) at the base of secondary lamellae which supported by an extension of cartilaginous matrix of gill filaments (S). Stain H\&E. X200 in A and C while X400 In B, and D. secondary lamella (Fig. 4I/L2). With a higher magnification, the surface of the filaments and lamellae is covered by longitudinal rows of epithelial cells (Fig. 4J).

Histologically, the gill filaments arise from gill arch in a perpendicular manner while they are parallel to each other (Fig. 6). Each filament is made up of a thin cartilaginous core representing an extension from that of gill arch while, the major parts of both sides are made of peripheral cartilaginous matrix that extends to support the basal portion of secondary lamellae (Fig. 6D). The filaments are covered by primary epithelial layer with many mucous cells interspersed in it. The chloride cells appeared as large flattened cells with slightly acidophilic cytoplasm and scattered in the interlamellar epithelium and mainly near to the base of secondary lamellae (Fig. 6A, B and C).

Each gill filament gave rise to very large number of secondary lamellae parallel to each other on both sides of gill filaments. The afferent arterioles appeared at the base of secondary lamellae. The epithelial layer is extended to cover the contra lateral secondary lamellae, while internally the lamellae are made up mainly of blood spaces. The epithelial lining of the secondary lamellae comprised epithelial pavement cells, few mucous cells and pillar cells. The pillar cells interposed the enriched blood capillaries (Fig. 6D).

\section{DISCUSSION}

The present study documents the morphology of L. sceleratus gills with its characteristic gill cover related to significant adaptive modifications different from that present in most teleost fish. Many studies of teleost gills have described the morphological and 
functional characteristics of gill epithelial cells (Carmona et al., 2004). These cells participate in various functions, such as gas exchange, maintenance of blood acid-base balance and ionic regulation (Brown, 1992; Laurent et al., 1994a, 1994b; Moron \& Fernandes, 1996; Fernandes et al., 1998; Goss et al., 1998; Sturla et al., 2001).

From the previous data, the anatomical position and shape of the gill opening is very important as it is explain the physiological contradictions between fish species. Many authors reported that the gill chamber of most teleost fish was bounded laterally by the operculum which closing the ventrolaterally opened gill opening which different in its position and mechanism of action (Eiras-Stofella \& CharvetAlmeida, 1997, 2000; Alsafy, 2013; Elsheikh, 2013). Our finding noted that, the gill cavity was bounded laterally by a three layered gill covering which consisting of; outer cutaneous layer and the middle bony supportive layer while the third internal layer is a muscular layer. On the other hand, the gill slits are a characteristic feature to cartilaginous fish such as sharks and rays, in which they are characterized by the absence of a single outer gill cover and replace by individual openings to gills (Gerhart et al., 2005).

Our study revealed that the gill opening was represented by slit-like opening without distinct opercular cover which presented cranial to the base of the pectoral fin and bounded by a cutaneous flap with underlying valvelike membrane which guards the opening. This is similar to the results revealed by (Zayed \& Mohamed) in the catfish that has a small gill opening. This variation of gill opening was explained by Greenwood \& Norman (1963) which reported that fishes with a wide external gill opening die more rapidly than those in which have a small opening. In the present study, we suggest that, this characteristic position and shape of the gill opening was related to the Inflationary behavior of fish which is considered one of the defense mechanism of puffer fish (L. sceleratus), during any dangerous situation.

There are great variations in the number of gills between the different fish species; in the present study there are three pairs of gills, however, four pairs of gills is the common number in most teleost fishes (Hughes \& Grimstone, 1965; Hughes \& Morgan; Hossler et al., 1985; Eiras-Stofella et al., 2001; Eiras-Stofella \& Fank-deCarvalho, 2002; Zayed \& Mohamed; Cinar et al., 2009; Díaz et al., 2009; Kumari et al., 2009, 2012; Alsafy; Elsheikh). However, there are five pairs of gills but the fifth pair is ill developed and devoid from any gill filaments as noted in catfish (Zayed \& Mohamed; Kumari et al., 2005; Elsheikh), in contrast, in Senegal sole (Arellano et al., 2004) reported that the fifth pair is well-developed and contain gill filaments. Moreover, the cartilaginous fish have five to seven pairs of gills, and primitive jawless fish have seven pairs of gills (Romer, 1949).

There is a close relation between the morphologic specialization of the gill rakers and feeding behavior (Hyatt, 1979; Ojha et al., 1987; Ghosh et al., 1988; Eiras-Stofella et al.; Liston, 2013; Salman et al., 2005). Liston and Salman et al. reported that, the rakers acts as a barrier to water flow rather than as a sieve, in which they direct the water toward the roof of the oral cavity where the food particles were trapped by their mucous covering before being ingested.

The present study reported that, the rostral extremities of gill arches were united forming a wide interbranchial septum between the contra-lateral gills as reported by (Zayed \& Mohamed; Alsafy), furthermore, there is a quadrilateral interbranchial septum carrying a line of rough spiny small rakers at the level ventromedial to the third gill on both sides.

Our results revealed that $L$. sceleratus gills were characterized by a somewhat clear angle of curvature at the union of short epibranchials and long ceratobranchials as reported in many literatures (Eiras-Stofella \& CharvetAlmeida, 1998, 2000; Kumari et al., 2005; Alsafy), in contrast, there are some species that were characterized by the absence of this angle as noted by (Hossler et al., 1979; Eiras-Stofella et al.). However, other types of fishes exhibit an acute angle of curvature, almost in the middle of the gill arches like that found in freshwater fish Hypostomus eommersollii Val (Eiras-Stofella \& Charvet-Almeida, 1997).

The appearance of gill rakers and the method of their organization on the gill arch showed wide variation between different fish types. The current findings indicate presence of three rows of gill rakers surrounded by spines on each gill arch; two lateral rows (small-sized row and other accessory one) and medial row of slightly larger-sized rakers. These three rows could increase the efficiency of the puffer fish (L. sceleratus) in selective sorting of food particles. In this regard, the three rows of gill rakers were also reported in catfish (Zayed \& Mohamed) and in Clarias gariepinus (Elsheikh). Although, the presence of two rows of rakers on gill arches is common in many fishes (Hossler et al., 1985; Abuzinadah, 1995; Zayed \& Mohamed; Salman et al.; Díaz et al., 2009; Alsafy; Elsheikh).

The inter-raker spaces between adjacent gill rakers is considered an important factor that determines the size of the food particles to be swallowed, this factor is related to the feeding behavior of fish as the minimum spacing between the gill rakers determines the minimum size of prey that can 
be eaten (Magnuson \& Heitz, 1971; O’Brien, 1987). There are two types of fish according to inter-raker space; the first type is a narrow inter-raker space fish, which is adapted to small sized food items as in Indian major carp (Kumari et al., 2009) and in Mugil curema, M. liza, and M. platanus (Eiras-Stofella et al.). The second type is a wide inter-raker space fish, which adapted to large sized food items as in carnivorous, piscivorous, crustacean-feeder fishes as in; Oreochromis niloticus (Elsheikh) and in Gahash Lethrinus mahsena (Salman et al.). However, in some carnivorous species, there are narrow inter-raker spaces as in; Gymnoclytia unicolor, Caranx sexfasciatus (Abuzinadah) and this agreed with our findings.

Our scanning results clarified presence of many taste buds on both gill arches and rakers to increase the efficiency in selective sorting of palatable food. In our finding, the occurrence of a great number of taste buds together with sharp teeth suggests that food processing and gestation work occur simultaneously in the pharynx and this may determine the suitability of potential food items prior to swallowing, as proposed by (Linser et al., 1998) in Micropterus salmoides. The presence of taste buds in the gills of all fishes was related to their role in participation in tasting process at the pharyngeal region, in which the taste buds are the sense organs of the gustatory system of fish and resemble that present in other vertebrates (Kasumyan, 1997; Fishelson et al., 2004). In the puffer fish (L. sceleratus), the presence of many taste buds in the gill arch and gill rakers resemble that noted by (Ghosh et al.; Kumari et al., 2005; Díaz et al., 2009).

In the present study, our results demonstrated presence of the longitudinal parallel ridges covering both gill arches and gill filaments, suggested to have a functional role to increase the surface area to trap, convening and distributing mucus, and providing reserve surface areas for stretching (Kumari et al., 2005) proposed to the functional roles of microridges to enhance the mechanical flexibility and provide greater surface firmness of gill arches and rakers. Although the presence of microridges may form intricate patterns in several other fish species (Hossler et al., 1985; Ojha et al.; Eiras-Stofella \& Charvet-Almeida, 1997; EirasStofella et al.; Kumari et al., 2005; Díaz et al., 2009).

Our results revealed that the length of gill filaments has a little variation along the whole length of gill arches, where, the gill filaments appeared longer in the middle, being shorter toward the extremities as mentioned by (Díaz et al., 2009) in Odontesthes argentinensis. Moreover, in freshwater fish Prochilodus scrofa Steindachner and in seawater Eugerres brasilianus, the gill filaments are shorter on both extremities of gill arch and in the strong curvature angle region (Eiras-Stofella \& Charvet-Almeida, 1998, 2000), however (Kumari et al., 2012) in catfish and Carp reported that, in gill arch the length of gill filaments is shorter on one side than the other.

The results of scanning and histological microscopy of the present study agree with the findings of (Kudo \& kImura, 1984; Evans et al., 2005) that, secondary gill filaments were originated at the right angles to the long axis of primary gill filaments and the secondary lamellae were lying parallel to each other. Interestingly, the present study showed presence of tertiary lamellae, originated from some secondary lamellae as noted by (Hughes \& Mittal, 1980; Arpigny et al., 2012) and expected to increase the respiratory surface area within the gills

The morphology and distribution of the different cell types of the gill epithelium of teleosts have been intensively investigated in order to understand and recognize the integration of several of their functions (Wilson \& Laurent, 2002; Díaz et al., 2010; Monteiro et al., 2010). Our histological finding investigated that filaments are covered by primary epithelial layer with many mucous cells interspersed in it. Although the number of mucous cells was fewer in the secondary lamellae, in agreement with findings of (Tano de la Hoz et al., 2014). Mucus elaborated by mucous cells in the epithelium of the gill arches and rakers may be involved in lubrication, helping the smooth passage of food items through the pharynx, thus protecting the epithelium from mechanical injury (Grau et al., 1992; Tibbetts, 1997; Alsafy). Moreover, the mucous cells were involved in fish immune responses during infections (Vigliano et al., 2006; Bermudez et al., 2010).

In our work results, the chloride cells appeared as large flattened cells with slightly acidophilic cytoplasm and scattered in the interlamellar epithelium, mainly near the base of secondary lamellae. As in all other teleosts, in $L$. sceleratus gills, the chloride cells must play an important role in osmoregulation. According to results of (Varsamos et al., 2002), there is no strict separation in function between filament and lamellar epithelium, as chloride cells were also observed in the lamellar region of sea bass gills. In contrast to freshwater specimens, seawater-acclimated fish showed a marked increase in the number and size of chloride cells (Carmona et al.). Moreover, the peripheral cartilaginous matrix of gill filaments extends to support the basal portion of secondary lamellae.

In our histological finding, the epithelial layer of gill filaments extends to cover the contra lateral secondary lamellae, while internally the lamellae are made up mainly of blood spaces interposed by pillar cells which have an 
important role during gas exchange. The function of the pillar cells is related to their contractile filaments that have a crucial role in control of blood flow through the secondary lamellae and in reducing the pressure drop during the flow of blood across the gills of fish (Bettex-Galland \& Hughes, 1973). On both sides of lamellar epithelium, there are squamous pavement cells and few mucous and chloride cells. This is in agreement with that of (Tano de la Hoz et al.) in Odontesthes argentinensis. We suggest that the decreased number of both mucous and chloride cells in the secondary lamellar epithelium of L. sceleratus may reflect that the major role of these cells occurs in the primary epithelium of gill filament while the secondary lamellar epithelium is mainly responsible for gas exchange.

\section{CONCLUSION}

We concluded that although the Lagocephalus sceleratus shared the same marine living and feeding habits, we noticed some characteristic features in the arrangement, size and number of gill arches, filaments and rakers. The presence of mucous cells pointed to the adaptive modifications of the food and feeding ecology of Lagocephalus sceleratus. The gill filaments carried many chloride cells that adapted to osmoregulation in the salt water environment. While the pillar cells between the blood spaces of secondary lamellae are mainly acting during gas exchange.

ABUMANDOUR, M. M.A. \& GEWAILY, M. S. Estudios morfológicos en branquias del pez globo (Lagocephalus Sceleratus, Gmelin, 1789). Int. J. Morphol., 34(3):817-829, 2016.

RESUMEN: El objetivo fue estudiar la morfología de las branquias de Sceleratus L. desde la anatomía macroscópica, microscopía electrónica de barrido, así como la microscopía de luz. Los resultados revelaron que las aberturas branquiales aparecían como simples rendijas por delante de la aleta pectoral sin una cubierta opercular distinta. El sistema branquial consistió en tres pares de arcos branquiales con dos filas de branquiespinas en sus filamentos branquiales frontales y cóncavos en el margen. La microscopía de barrido mostró que todas las superficies del arco branquial se caracterizaron por la presencia de crestas longitudinales con muchas papilas gustativas, además de una cantidad importante de espinas alrededor de los rastrillos. Histológicamente, el arco branquial se compone de una barra curva de cartílago hialino con una zona ligeramente elevada, correspondiente a los sitios de branquiespinas. Cada filamento se formó por un delgado núcleo central cartilaginoso rodeado de matriz cartilaginosa periférica y cubierto por una capa epitelial primaria con abundantes células mucosas. Las células de cloruro aparecieron principalmente cerca a la base de laminillas secundaria. Cada filamento de las branquias en ambos lados dio origen a un gran número de laminillas secundarias. El revestimiento epitelial de laminillas secundarias estaba formado de células epiteliales, algunas células mucosas y células sostenedoras. Estos hallazgos sugieren que las branquias de $L$. sceleratus tienen características morfológicas que están relacionadas con las funciones de adaptación de los hábitos de alimentación, la osmorregulación y el mecanismo respiratorio de acuerdo a su entorno.

PALABRAS CLAVE: Lagocephalus sceleratus; Branquias; Anatomía ; Microscopía electrónica de Barrido; Histología.

\section{REFERENCES}

Abuzinadah, O. A. Gill raker morphology in some red sea fishes of different feeding preferences. JKAU Mar. Sci., 6:93-122, 1995.

Alsafy, M. A. Gill morphology in two Mediterranean Sea fishes of similar feeding preferences: sea bream (Sparus aurata L) and sea bass (Dicentrarchus labrax). Vet. Res. Commun., 37(2):16370, 2013.

Arellano, J. M.; Storch, V. \& Sarasquete, C. Ultrastructural and histochemical study on gills and skin of the Senegal sole, Solea senegalensis. J. Appl. Ichthyol., 20(6):452-60, 2004.

Arpigny, J. L.; Coyette, J.; Davail, S.; Feller, G.; Fonze, E.; Foulkes, E. C.; Frere, J. M.; Fujii, R.; Genicot, S. \& Gerday, C. Advances in Comparative and Environmental Physiology. Heidelberg, Springer, 2012.
Balm, P. H. M. Trycophrya intermedia on the gills of rainbow trout acclimating to low ambient pH. J. Fish Biol., 48:147-50, 1996.

Bermúdez, R.; Losada, A. P.; Vázquez, S.; Redondo, M. J.; AlvarezPellitero, P. \& Quiroga, M. I. Light and electron microscopic studies on turbot Psetta maxima infected with Enteromyxum scophthalmi: histopathology of turbot enteromyxosis. Dis. Aquat. Organ., 89(3):209-21, 2010.

Bettex-Galland, M. \& Hughes, G. M. Contractile filamentous material in the pillar cells of fish gills. J. Cell Sci., 13(2):359-70, 1973.

Bilecenoglu, M.; Kaya, M. \& Akalin, S. Range expansion of silverstripe blaasop, Lagocephalus sceleratus (Gmelin, 1789), to the northern Aegean Sea. Aquat. Invasions, 1(4):289-91, 2006. 
Brown, P. Gill chloride cell surface-area is greater in freshwateradapted adult sea trout (Salmo trutta, L.) than those adapted to sea water. J. Fish Biol., 40(3):481-4, 1992.

Carmona, R.; García-Gallego, M.; Sanz, A.; Domezaín, A. \& OstosGarrido, M. V. Chloride cells and pavement cells in gill epithelia of Acipenser naccarii: ultrastructural modifications in seawateracclimated specimens. J. Fish Biol., 64(2):553-66, 2004.

Carpentieri, P.; Lelli, S.; Colloca, F.; Mohanna, C.; Bartolino, V.; Moubayed, S. \& Ardizzone, G. D. Incidence of lessepsian migrants on landings of the artisanal fishery of south Lebanon. Mar. Biodivers. Rec., 2:e71, 2009.

Cinar, K.; Aksoy, A.; Emre, Y. \& Assti, R. N. The histology and histochemical aspects of gills of the flower fish, Pseudophoxinus antalyae. Vet. Res. Commun., 33(5):453-60, 2009.

Díaz, A. O.; Castro, M. G.; García, A. M.; Díaz de Astarloa, J. M. \& Figueroa, D. E. Gross morphology and surface ultrastructure of the gills of Odontesthes argentinensis (Actinopterygii, Atherinopsidae) from a Southwestern Atlantic coastal lagoon. Tissue Cell, 41(3):193-8, 2009.

Díaz, A. O.; García, A. M.; Escalante, A. H. \& Goldemberg, A. L. Glycoproteins histochemistry of the gills of Odontesthes bonariensis (Teleostei, Atherinopsidae). J. Fish Biol., 77(7):1665-73, 2010.

Eiras-Stofella, D. R. \& Charvet-Almeida, P. Gills of the freshwater fish Hypostomus commersonii Val., 1840 (Loricariidae) analyzed through electron microscopy techniques. Braz. Arch. Bio. Technol., 40:785-92, 1997.

Eiras-Stofella, D. R. \& Charvet-Almeida, P. Ultrastructure (SEM) of the gills of Prochilodus Scrofa Steindachner (Pisces, Teleostei). Rev. Bras. Zool., 15(2):279-87, 1998.

Eiras-Stofella, D. R. \& Charvet-Almeida, P. Gills scanning images of the seawater fish Eugerres brasilianus (Gerreidae). Braz. Arch. Biol. Technol. [Internet], 43(4), 2000. Available from: http:/ /www.scielo.br/scielo.php?script $=$ sci_arttext\&pid $=$ S1516$89132000000400011 \& \operatorname{lng}=$ en. http://dx.doi.org/10.1590/ S1516-89132000000400011

Eiras-Stofella, D. R.; Charvet-Almeida, P.; Fanta, E. \& Vianna, A. C. Surface ultrastructure of the gills of the mullets Mugil curema, M. liza and M. platanus (Mugilidae, Pisces). J. Morphol., 247(2):122-33, 2001.

Eiras-Stofella, D. R. \& Fank-de-Carvalho, S. M. Morphology of gills of the seawater fish Cathorops spixii (Agassiz) (Ariidae) by scanning and transmission electron microscopy. Rev. Bras. Zool., 19(4):1215-20, 2002.

Elsheikh, E. H. Scanning electron microscopic studies of gill arches and rakers in relation to feeding habits of some fresh water fishes. J. Basic Appl. Zool., 66(3):121-30, 2013.
Evans, D. H.; Piermarini, P. M. \& Choe, K. P. The multifunctional fish gill: dominant site of gas exchange, osmoregulation, acidbase regulation, and excretion of nitrogenous waste. Physiol. Rev., 85(1):97-177, 2005.

Fernandes, M. N.; Castro, F. J. \& Mazon, A. F. Scanning electron microscopy of the gill raker of the Loricariid fish, Rhinelepis strigosa. Acta Microsc., 12:511-2, 2003.

Fernandes, M. N.; Perna, S. A. \& Moron, S. E. Chloride cell apical surface changes in gill epithelia of the armoured catfish Hypostomus plecostomus during exposure to distilled water. J. Fish Biol., 52(4):844-9, 1998.

Fishelson, L.; Delarea, Y. \& Zverdling, A. Taste bud form and distribution on lips and in the oropharyngeal cavity of cardinal fish species (Apogonidae, Teleostei), with remarks on their dentition. J. Morphol., 259(3):316-27, 2004.

Gerhart, J.; Lowe, C. \& Kirschner, M. Hemichordates and the origin of chordates. Curr. Opin. Genet. Dev., 15(4):461-7, 2005 .

Ghosh, T. K.; Singh, O. N.; Roy, P. K. \& Munshi, J. S. D. Morphometrics and surface ultrastructure of gill rakers of three Indian teleostean fishes. Proc. Indian Natl. Sci. Acad., B54(5):331-6, 1988.

Goss, G. G.; Laurent, P. \& Perry, S. F. Evidence for a morphological component in acid-base regulation during environmental hypercapnia in the brown bullhead (Ictalurus nebulosus). Cell. Tissue Res., 268(3):539-52, 1992.

Goss, G. G.; Perry, S. F.; Fryer, J. N. \& Laurent, P. Gill morphology and acid-base regulation in freshwater fishes. Comp. Biochem. Physiol. A Mol. Integr. Physiol., 119(1):107-15, 1998.

Grau, A.; Crespo, S.; Sarasquete, M. C. \& González de Canales, M. L. The digestive tract of the amberjack Seriola dumerili, Risso: a light and scanning electron microscope study. J. Fish Biol., 41(2):287-303, 1992.

Greenwood, J. R. \& Norman, P. H. A History of Fishes. $2^{\text {nd }}$ ed. London, Ernest Benn Limited, 1963.

Homaira, N.; Rahman, M.; Luby, S. P.; Rahman, M.; Haider, M. S.; Faruque, L. I.; Khan, D.; Parveen, S. \& Gurley, E. S. Multiple outbreaks of puffer fish intoxication in Bangladesh, 2008. Am. J. Trop. Med. Hyg., 83(2):440-4, 2010.

Hossler, F. E.; Musil, G.; Karnaky, K. J. Jr. \& Epstein, F. H. Surface ultrastructure of the gill arch of the killifish, Fundulus heteroclitus, from seawater and freshwater, with special reference to the morphology of apical crypts of chloride cells. J. Morphol., 185(3):377-86, 1985.

Hossler, F. E.; Ruby, J. R. \& McIlwain, T. D. The gill arch of the mullet, Mugil cephalus. I. Surface ultrastructure. J. Exp. Zool., 208(3):379-97, 1979. 
Hughes, G. M. \& Mittal, A. K. Structure of the gills of Barbus sophor (Ham), a cyprinid with tertiary lamellae. J. Fish Biol., 16(4):461-7, 1980.

Hughes, G. M. \& Grimstone, A. V. The fine structure of the secondary lamellae of the gills of Gadus pollachius. J. Cell Sci., s3-106:343-53, 1965.

Hughes, G. M. \& Morgan, M. The structure of fish gills in relation to their respiratory function. Biol. Rev., 48(3):419$75,1973$.

Hyatt, K. D. Feeding Strategy. In: Hoar, W. S.; Randall, D. J. \& Brett, J. R. (Eds.). Fish Physiology. Vol. VIII. New York, Academic Press, 1979.

Kalogirou, S.; Corsini-Foka, M.; Sioulas, A.; Wennhage, H. \& Pihl, L. Diversity, structure and function of fish assemblages associated with Posidonia oceanica beds in an area of the eastern Mediterranean Sea and the role of non-indigenous species. J. Fish Biol., 77(10):2338-57, 2010.

Kasapidis, P.; Peristeraki, P.; Tserpes, G. \& Magoulas, A. First record of the Lessepsian migrant Lagocephalus sceleratus (Gmelin 1789) (Osteichthyes: Tetraodontidae) in the Cretan Sea (Aegean, Greece). Aquat. Invasions, 2(1):71-3, 2007.

Kasumyan, A. O. Gustatory reception and feeding behaviour in fish. J. Ichthyol., 37:78-93, 1997.

Kudo, S. \& Kimura, N. Scanning electron microscopic studies on bacterial gill disease in rainbow trout fingerlings. Japan J. Ichthyol., 30:393-403, 1984.

Kumari, U.; Mittal, S. \& Mittal, A. K. Surface ultrastructure of the gill filaments and the secondary lamellae of the catfish, Rita rita, and the carp, Cirrhinus mrigala. Microsc. Res. Tech., 75(4):433-40, 2012.

Kumari, U.; Yashpal, M.; Mittal, S. \& Mittal, A. K. Morphology of the pharyngeal cavity, especially the surface ultrastructure of gill arches and gill rakers in relation to the feeding ecology of the catfish Rita rita (Siluriformes, Bagridae). J. Morphol., 265(2):197-208, 2005.

Kumari, U.; Yashpal, M.; Mittal, S. \& Mittal, A. K. Surface ultrastructure of gill arches and gill rakers in relation to feeding of an Indian major carp, Cirrhinus mrigala. Tissue Cell, 41(5):318-25, 2009.

Laurent, P.; Dunel-Erb, S.; Chevalier, C. \& Lignon, J. Gill epithelial cells kinetics in a freshwater teleost, Oncorhynchus mykiss during adaptation to ion-poor water and hormonal treatments. Fish Physiol. Biochem., 13(5):353-70, 1994a.

Laurent, P.; Goss, G. G. \& Perry, S. F. Proton pumps in fish gill pavement cells? Arch. Int. Physiol. Biochim. Biophys., 102(1):77-9, 1994b.
Laurent, P. \& Hebibi, N. Gill morphometry and fish osmoregulation. Can. J. Zool., 67:3055-63, 1989.

Linser, P. J.; Carr, W. E.; Cate, H. S.; Derby, C. D. \& Netherton, J. C. 3rd. Functional significance of the co-localization of taste buds and teeth in the pharyngeal jaws of the largemouth bass, Micropterus salmoides. Biol. Bull., 195(3):273-81, 1998.

Liston, J. The Plasticity of Gill Raker Characteristics in Suspension Feeders: Implications for Pachycormiformes. In: Arratia, G.; Schultze, H.-P. \& Wilson, M. V. H. (Eds.). Mesozoic Fishes 5 - Global Diversity and Evolution. München, Verlag Dr. Friedrich Pfeil, 2013. pp.121-43.

Magnuson, J. J. \& Heitz, J. G. Gill raker apparatus and food selectivity among mackerels, tunas and dolphins. Fish. Bull., 69(2):361-70, 1971.

Monteiro, F. M.; Dutkiewicz, S. \& Follows, M. J. Biogeographical controls on the marine nitrogen fixers. Glob. Biogeochem. Cycles, 25(2):GB2003, 2011.

Monteiro, S. M.; Oliveira, E.; Fontaínhas-Fernandes, A. \& Sousa, M. Fine structure of the branchial epithelium in the teleost Oreochromis niloticus. J. Morphol., 271(5):621-33, 2010.

Moodie, G. E. E. Gill raker variation and the feeding niche of some temperate and tropical freshwater fishes. Environ. Biol. Fish., 13(1):71-6, 1985.

Moron, S. E. \& Fernandes, M. N. Pavement cell ultrastructural differences on Hoplias malabaricus, gill epithelia. J. Fish Biol., 49(2):357-62, 1996.

Moyle, P. B. \& Cech, J. J. Jr. Fishes: An Introduction to Ichthyology. $3^{\text {rd }}$ ed. Upper Saddle River, Prentice Hall, 1996.

Mummert J. R. \& Drenner, R. W. Effect of size on filtering efficiency and selective particle ingestion of filter feeding clupeid. Trans. Am. Fish. Soc., 115(4):522-8, 1986.

Nader, M. R.; Indary, S. \& Boustany, L. E. The Puffer Fish Lagocephalus sceleratus (Gmelin, 1789) in the Eastern Mediterranean. Athens, Food and Agriculture Organization of the United Nations, EastMed GCP/INT/041/EC - GRE - ITA/ TD-10, 2012.

O'Brien, W. J. Planktivory by Freshwater Fish: Thrust and Parry in the Pelagia. In: Kerfoot, W.C., Sih, A. (Eds.). Predation: Direct and Indirect Effects on Aquatic Communities. New Hampshire, University Press of New England, 1987. pp.3-16.

Ojha, J.; Mishra, A. K. \& Munshi, J. S. D. Interspecific variations in the surface ultrastructure of the gills of freshwater mullets. Jpn. J. Ichthyol., 33(4):388-93, 1987.

Pancucci-Papadopoulou, M.; Corsini-Foka, M. \& Raitsos, D. E. Alien Invasions and Climatic Changes: the South-Eastern Aegean Experience. Rhodes, Proceedings of the International 
Conference on Environmental Science and Technology, 2011. Available from: http://www.srcosmos.gr/srcosmos/ showpub.aspx?aa=15137

Peristeraki, P.; Lazarakis, G.; Skarvelis, C.; Georgiadis, M. \& Tserpes, G. Additional records on the occurrence of alien fish species in the eastern Mediterranean Sea. Mediterr. Mar. Sci., 7(2):61-6, 2006.

Romer, A. S. The Vertebrate Body. Philadelphia, Saunders, 1949.

Saliu, J. K. \& Olonire, G. T. A comparative study of the gill anatomy of Clarias anguillaris, Chrysichthys longifilis and Synodontis membranaceus from Asia reservoir and Kainji reservoir, Nigeria. Life Sci. J., 5(1):85-7, 2008.

Salman, N. A.; AL-Mahdawi, G. J. \& Heba, H. M. Gill rakers morphology and filtering mechanism in some marine teleosts from Red Sea coasts of Yemen. Egypt. J. Aquat. Res., 31:28696, 2005.

Smith, M. M. \& Heemstra, P. C. Tetraodontidae. In: Smith, M. M. \& Heemstra, P. C. (Eds.). Smiths' Sea Fishes. Berlin, Springer-Verlag, 1986. pp.894-903.

Streftaris, N. \& Zenetos, A. Alien marine species in the Mediterranean - the 100 'Worst Invasives' and their impact. Mediterr. Mar. Sci., 7(1):87-118, 2006.

Sturla, M.; Masini, M. A.; Prato, P.; Grattarola, C. \& Uva, B. Mitochondria-rich cells in gills and skin of an African lungfish, Protopterus annectens. Cell Tissue Res., 303(3):351-8, 2001.

Suvarna, S. K.; Layton, C. \& Bancroft, J. D. Bancroft's Theory and Practice of Histological Techniques. $7^{\text {th }}$ ed. Singapore, Elsevier, 2013.

Tano de la Hoz, M. F.; García, A. M.; González Castro, M. \& Díaz, A. O. Histochemical and scanning electron microscopic approaches to gills in juveniles of Odontesthes argentinensis (Actinopterygii, Atherinopsidae). Int. J. Aquat. Sci., 5:15466, 2014.

Tibbetts, I. R. The distribution and function of mucous cells and their secretions in the alimentary tract of Arrhamphus sclerolepis krefftii. J. Fish Biol., 50(4):809-20, 1997.

Varsamos, S.; Diaz, J. P.; Charmantier, G.; Flik, G.; Blasco, C. \& Connes, R. Branchial chloride cells in sea bass (Dicentrarchus labrax) adapted to fresh water, seawater, and doubly concentrated seawater. J. Exp. Zool., 293(1):12-26, 2002.

Vigliano, F. A.; Bermúdez, R.; Quiroga, M. I. \& Nieto, J. M. Evidence for melano-macrophage centres of teleost as evolutionary precursors of germinal centres of higher vertebrates: an immunohistochemical study. Fish Shellfish Immunol., 21(4):467-71, 2006.
Watson, R.; Pauly, D.; Christensen, V.; Froese, R.; Longhurst, A.; Platt, T.; Sathyendranath, S.; Sherman, K.; O'Reilly, J. \& Celone, P. Mapping Fisheries onto Marine Ecosystems for Regional, Oceanic and Global Integrations. In: Hempel, G. \& Sherman, K. (Eds.). Large Marine Ecosystems of the World: Trends in Exploitation, Protection, and Research. Amsterdam, Elsevier, 2003. pp.365-96.

West, M. D. Haley and the Blowfish. Wash. U. Global Stud. L. Rev., 8(2):427-42, 2009.

Wilson, J. M. \& Laurent, P. Fish gill morphology: inside out. J. Exp. Zool., 293(3):192-213, 2002.

Zayed, A. E. \& Mohamed, S. A. Morphological study on the gills of two species of fresh water fishes: Oreochromis niloticus and Clarias gariepinus. Ann. Anat., 186(4):295-304, 2004.

Zenetos, A.; Çinar, M. E.; Pancucci-Papadopoulou, M.; Harmelin, J. G.; Furnari, G.; Andaloro, F.; Bellou, N.; Streftaris, N. \& Zibrowius, H. Annotated list of marine alien species in the Mediterranean with records of the worst invasive species. Mediterr. Mar. Sci., 6(2):63-118, 2005.

Correspondence to:

Mohamed M. A. Abumandour,

Assistant Professor of Anatomy and Embryology

Faculty of Veterinary Medicine

Alexandria University

Anatomy and Embryology Department

Rashid, Edfina

Behera

EGYPT

Post Box: 22785

Mob. +201000322937

Fax: +20452960450

Email: m.abumandour@yahoo.com

Received: 06-01-2016

Accepted: 05-05-2016 